\section{New Protocol for DNA Extraction of Stool}

BioTechniques 28:286-290 (February 2000)

\begin{abstract}
Present methods for DNA isolation of stool have various limitations such as the amount of stool used, the requirement of lavage fluids or the use of fresh stool. In this paper, a new method is described for the isolation of human nucleic acids from stool, which is independent from the moment of collection. Fecal samples as dry as possible were collected from 75 patients; two grams of stool were mixed with a lysis buffer containing phenol. DNA yields of crude stool were variable and ranged from 9-1686 $\mu \mathrm{g} / \mathrm{g}$ of feces. With dot blots in 9 of the 75 cases, the human DNA was identified and ranged from $0.06 \%-46 \%$. In the remaining 66 cases, human genomic DNA was detected by nested PCR, using human K-ras gene amplification as an example. Amplification products were confirmed for human $K$-ras with the exonuclease-amplification coupled capture technique (EXACCT). In conclusion, the developed DNA isolation method can be used for the study of large numbers of stool samples, is independent of the age or method of stool collection and is suitable for large-scale screening studies.
\end{abstract}

\section{INTRODUCTION}

Secondary prevention of colorectal cancer by means of screening stool for tumor cells is a recent and promising field of research. $(16,17)$ Several studies have been reported on the detection of K-ras $(7,16,17)$ and other mutations $(5,21)$ in exfoliated cells of stool $(12,16,17)$ or colonic lavage fluids $(18,21)$. The methods reported for DNA extraction are quite varied $(9,17)$, and specific restrictions are frequently required, such as the fresh collection of stool, the use of colonic effluents, colonic wash, direct isolation or storage at $-70^{\circ} \mathrm{C}(5,7,11,13,15)$. Fresh collection is used in most studies and may be feasible in an experimental setting, but is not a useful characteristic for population-based screening. A similar reasoning also applies to the use of colonic ef- fluent samples after colonic wash. Stool collection by the patient at home without any prerequisites would be the best way for population-based screening. Up to now, DNA isolated from normal stool could only be amplified with variable success $(5,7,11)$, which precluded the use of normal stool for DNA analysis.

Normally, $80 \%$ of the water content from fecal material is reabsorbed in the large bowel (6). Thus, a certain state of fecal dehydration may occur, which results in inactivation of degradative enzymes. Conversely, adding water to stool results in a rapid breakdown of nucleic acids. In fact, soft rocks in Egypt's desert along the Nile are actually dehydrated dromedary droppings, probably present since the last rainfall (21). Based on the concept of relative dehydration of stool, the purpose of this study was to develop a simple method for DNA isolation, which has little or no specific requirements at the time of stool collection and so can be used for further specific DNA analysis in population-based studies.

\section{MATERIALS AND METHODS}

\section{DNA Isolation of Fecal Samples}

Fecal samples from 75 patients visiting the outpatient clinics of the department of surgery at Maastricht University Hospital were collected as dry as possible and kept in a closed tube at room temperature for $24-48 \mathrm{~h}$ before DNA isolation was initiated. Two grams of stool were resuspended in a $15 \mathrm{~mL}$ tube containing a lysis buffer with two liquid phases at $4^{\circ} \mathrm{C}$. One consisted of $4 \mathrm{~mL}$ PBS $(115 \mathrm{mM} \mathrm{NaCl}, 8$ $\left.\mathrm{mM} \mathrm{KCL}, 1.6 \mathrm{mM} \mathrm{KH} \mathrm{PO}_{4} \mathrm{pH} 7.4\right)$ with $0.9 \%$ SDS and $18 \mathrm{mM}$ EDTA, and the other consisted of $4 \mathrm{~mL}$ phenol/ chloroform/isoamyl alcohol (IAA, 25: 24:1) buffered at $\mathrm{pH}$ 8. Approximately $1 \mathrm{~g}$ of glass beads with a diameter of 1 $\mathrm{mm}$ (Emergo, Landsmeer) was added for mechanical resuspension of the stool. The beads were pretreated overnight with $0.25 \mathrm{M} \mathrm{HCl}$ and washed in distilled water until the $\mathrm{pH}$ was neutral before use.

After being vigorously stirred, the mixture was heated to $65^{\circ} \mathrm{C}$ for $10 \mathrm{~min}$ and rapidly frozen in a dry ice/ethanol
Table 1. Distribution of Total DNA Yield $(\mu \mathrm{g} / \mathrm{g}$ Feces) in Relation to Samples Positive with Dot Blot for Human DNA

\begin{tabular}{|lcc|}
\hline $\begin{array}{c}\text { DNA Yield } \\
\mu \mathbf{g} / \mathbf{g}\end{array}$ & $\boldsymbol{n}^{\mathbf{a}}$ & $\begin{array}{c}\boldsymbol{n} \text { positive } \\
(\%)\end{array}$ \\
\hline $1-100$ & 24 & $5(21)$ \\
$100-200$ & 16 & $2(13)$ \\
$200-400$ & 13 & $1(8)$ \\
$400-800$ & 15 & $1(7)$ \\
$800-686$ & 7 & $0(0)$ \\
an number of samples & \\
\hline
\end{tabular}

bath or stored at $-70^{\circ} \mathrm{C}$ until further handling. The frozen samples were centrifuged at $286 \times g$ for $45 \mathrm{~min}$ at room temperature, during which thawing occured. Subsequently, the water phase was transferred to a clean tube and used for a second extraction with $4 \mathrm{~mL}$ phenol/chloroform/IAA (25:24:1). After another centrifugation at $286 \times g$ for 20 min at room temperature, $10 \%$ cetyltrimethylammonium bromide (CTAB), $0.7 \mathrm{M} \mathrm{NaCl}$ was added to the water phase to a final concentration of $2.3 \%$ CTAB, 0.16 M NaCl. Subsequently, two extractions with $4 \mathrm{~mL}$ chloroform/IAA (24:1) were performed. DNA was precipitated by the addition of $1 / 10 \mathrm{vol} 3 \mathrm{M}$ sodium acetate $\mathrm{pH} 5.2$ and $2.5 \mathrm{vol}$ of ethanol and placed for $20 \mathrm{~min}$ at $-20^{\circ} \mathrm{C}$. For further analysis, the DNA was dissolved in 200-500 $\mu \mathrm{L}$ sterile water, and $50 \mu \mathrm{g} / \mathrm{mL}$ RNAse were added. DNA concentrations of the samples were determined by $\mathrm{A}_{260 / 280}$ measurements.

\section{Dot Blot Analysis}

Dot blotting was performed as described by Maniatis et al. (12). From each of the fecal DNA samples, 10 and $20 \mu \mathrm{L}$ volumes were dissolved in 500 $\mu \mathrm{L} 6 \times$ standard saline citrate. As a reference, a serial dilution of human placental DNA that contained $1 \mu \mathrm{g}, 100$ ng, $10 \mathrm{ng}, 1 \mathrm{ng}, 100 \mathrm{pg}, 10 \mathrm{pg}$ and $1 \mathrm{pg}$, respectively per dot were blotted and hybridized simultaneously with the fecal samples. Hybridization was performed with human placental DNA as probe, labeled with $-32 \mathrm{P}$ dCTP using random priming labeling. The presence of human DNA was detected by count- 
Table 2. Dilutions of Fecal DNA that Give the First Positive Results on Agarose Gel for Variation in Cell Cycle with and without Spiking of Control Human DNA

\begin{tabular}{|lcrrrrrrl|}
\hline & $\begin{array}{c}\text { No. of } \\
\text { Cycles }\end{array}$ & $\mathbf{1 / 5}$ & $\mathbf{1 / 5 0}$ & $\mathbf{1 / 5 0 0}$ & $\mathbf{1 / 5 0 0 0}$ & $\mathbf{1 / 5 0 0 0 0}$ & Total \\
\hline After spiking & 40 & 1 & 20 & 33 & 18 & 3 & 75 \\
Wthout spiking & 40 & 0 & 2 & 10 & 15 & 11 & 38 \\
Without spiking & 70 & 6 & 22 & 38 & 9 & - & 75 \\
\hline
\end{tabular}

ing the hybridized radioactivity per dot in a Winspectral 1414 (Wallac, Turku, Finland) liquid scintillation counter. In each fecal sample, the amount of human DNA was estimated by the mean of duplicate samples and compared to the reference signals of human placental DNA. The mean plus three times the standard deviation of the background signal was arbitrarily chosen as the cutoff value for positivity.

\section{Amplification of Human DNA in a PCR}

Determination of the PCR. As an example for the amplification of a single copy, human gene primers specific for the human K-ras gene were used. Amplification and gel electrophoresis were performed as previously described (19). The reaction mixture contained primer 1 (sense, $5^{\prime}$-TTTTTATTATAAGGCCTGCTG-3') and primer 2 (antisense, 5'-TCAGAGAAACCTTTATCTGTATCAAAGAATGG-3'), both $4 \mathrm{ng} / \mu \mathrm{L}$, resulting in amplification of a 204 bp fragment. As template in the amplification reaction, $20 \mathrm{ng}$ per $20 \mu \mathrm{L}$ PCR volume of human $\mathrm{H} 716$ cell line DNA were spiked in serially diluted fecal DNA. The final concentration of fecal DNA in the PCR mixture (as a fraction of undiluted fecal DNA) was $1 / 5$, $1 / 50,1 / 500,1 / 5000$ and $1 / 50000$. The dilution $1 / 5$ was obtained by adding 4 $\mu \mathrm{L}$ of undiluted DNA to $20 \mu \mathrm{L}$ PCR total volume, which allowed identification of the dilution of stool DNA that permitted DNA amplification.

Identification of human DNA by nested PCR. The primers 1 and 2 (outside primers) are located just outside the first exon. For nested PCR, the same conditions were used with primer 3 (sense, 5'-ATGACTGAATATAAACTTGTGGTAG-3') and primer 4 (anti- sense, 5'-CCTCTATTGTTGGATCATATTCG-3') for 30 cycles. These nested primers resulted in amplification of a $112 \mathrm{bp}$ fragment containing the whole $111 \mathrm{bp}$ sequence of exon 1 .

\section{Amplification Product Identification by EXACCT}

The exonuclease-amplification coupled capture technique (EXACCT) improves detection of the PCR product (8).

\section{Statistical Analysis}

The distribution of total fecal DNA and outcome of the dot blots were evaluated with the chi-square test. $P$ values $<0.05$ were considered significant.

\section{RESULTS}

\section{DNA Extraction From Stool}

To keep the relative dehydrated state, fecal samples as dry as possible were collected and stored in tubes with closed lids at room temperature up to $48 \mathrm{~h}$. Before opening the tubes, the samples were cooled to $4^{\circ} \mathrm{C}$ and handled rapidly to avoid potential enzymatic degradation of nucleic acids. After mixing the fecal samples with lysis buffer and dissolving the isolated nucleic acids in distilled water, small samples were run on agarose gels to visually judge the DNA quality. The extracted water phase usually showed high molecular weight DNA and a smear with variable intensity. The treatment of the samples with RNAse A removed the smear component and demonstrated its RNA nature. Apparently, the dry storage of stool and rapid handling in the first steps resulted in isolation of both DNA and RNA. 
The amount of total DNA isolated for the stool samples ranged from 9-1686 $\mu \mathrm{g}$ DNA per gram of stool (mean $\pm \mathrm{SD}=$ $319 \pm 365 \mu \mathrm{g}$ DNA per gram of stool).

\section{Detection of Human DNA by Dot Blotting}

To quantify the amount of human DNA, dot blots of fecal DNA were hybridized with a human placental DNA probe. DNA quantities of 1-5 ng human reference DNA per dot were easily detectable, but lower amounts of human DNA usually gave no signal above the background threshold values (Figure 1). Control samples of the bacterial DNA did not hybridize with the human genomic DNA probe. Nine of the 75 fecal samples gave a distinct hybridization signal. In the majority of the cases, human genomic DNA could not be demonstrated with dot blot hybridization. By comparing the signals of the fecal samples with the reference values, an approximation was obtained for the amount of human DNA in each sample. The amount of human DNA as a fraction of total DNA ranged in the positive samples from $0.06 \%-46 \%$ (mean $11 \%$ ).

Table 1 shows the distribution of total amounts of isolated DNA and the outcome of the dot blot hybridization. Remarkably, a tendency towards an inverse relation was found between the amount of total DNA and positivity on dot blots. Seven of the nine cases with a detectable amount of human DNA on dot blot were obtained from samples with a DNA yield below the mean content $(P=0.28)$. In fact, DNA yields of those seven samples were even below $160 \mu \mathrm{g}$ DNA per gram of stool $(P=0.10)$. The dot blot results did not change when $10 \times$ less DNA were analyzed.

\section{Detection of Human DNA by PCR}

Because in most stool samples the human DNA could not be demonstrated with dot blot analyses, the presence of human DNA in all stool samples was further examined with PCR using primers specific for the human K-ras gene. The initial PCR with undiluted fecal DNA did not result in a visible band on agarose gels. To examine the presence of possible inhibitors in the PCR, serially diluted fecal DNA was spiked with a known amount of human control DNA as the template for amplification. For the different dilutions, the distribution of the number of spiked samples with the first positive signal is shown in Table 2. All samples showed a visible band for K-ras, although the dilutions in which a band was visible varied considerably. The final concen-

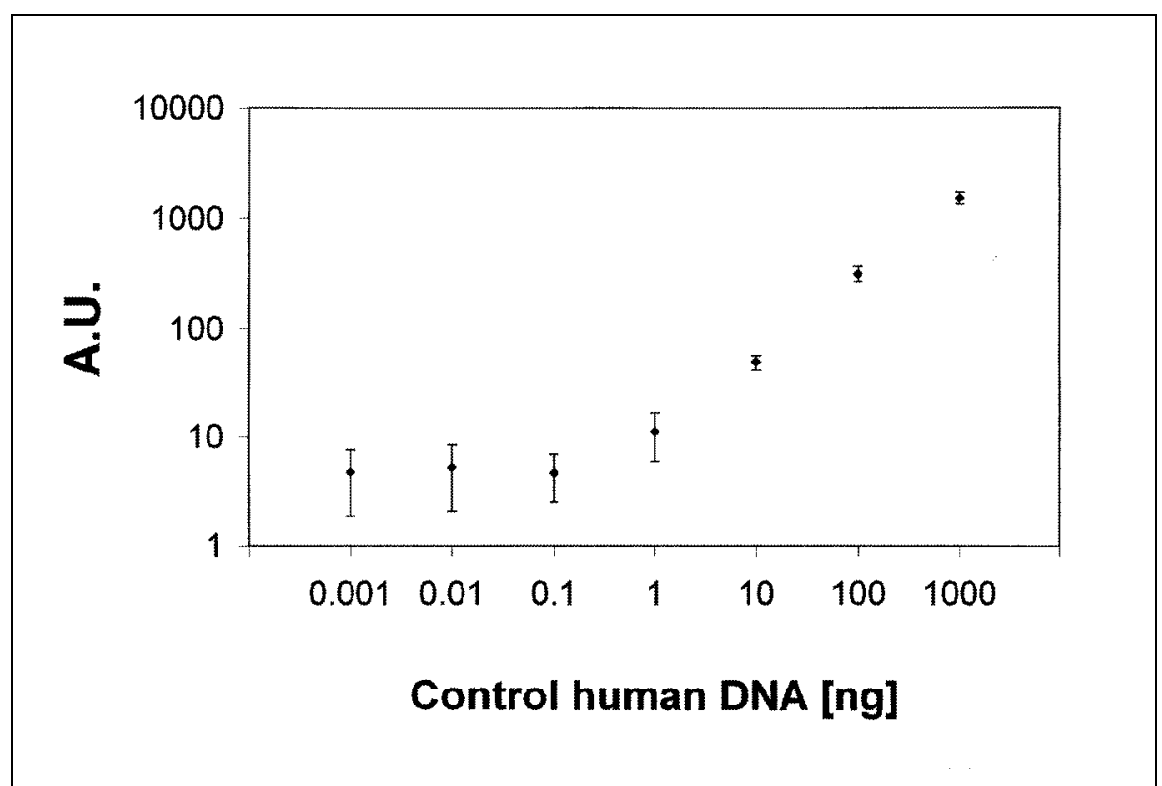

Figure 1. The mean and standard deviation of 9 blots are shown for the calibration points containing different amounts of human placental DNA. Note that amounts of DNA lower than $1 \mathrm{ng}$ are not detectable, that is, the signal is equal to background (A.U.= arbitrary units). tration of total fecal DNA in the spiked samples that allowed for first-time amplification of the human K-ras gene ranged from $0.018-13.200 \mathrm{ng} / \mu \mathrm{L}$ (mean $\pm \mathrm{SD}=2.2 \pm 3.0 \mathrm{ng} / \mu \mathrm{L}$ ). These results suggests the presence of inhibitor(s) in isolated fecal DNA.

To avoid the effect of inhibitors, fecal DNA dilutions for the unspiked PCR were based on the results of the spiking experiment with the first positive signal. In only 38 of 75 cases, a faint amplification product was found after 40 cycles of PCR. However, when nested PCR was performed, amplification of human genomic DNA could be demonstrated in all cases (Table 2). To confirm that the amplification products consisted of the human K-ras gene, the EXACCT procedure was performed. Clear spectrophotometer readouts proved the presence of human DNA in all samples.

Expressing the PCR in ratios of the amount of DNA maximally working in a PCR (up to $2 \mu \mathrm{g} / 100 \mu \mathrm{L}$ ) revealed that in 27 samples, the maximum DNA concentration was present where a PCR product was detected. In 41 samples, a $10 \times$ dilution was necessary, while a $100 \times$ dilution was necessary in the remaining seven samples before a PCR product of the correct size was visible.

We expected a positive PCR product within 40 cycles of amplification for $\mathrm{K}$-ras in the nine cases that were positive with dot blotting and had a large amount of human DNA. However, this was so in only six of the nine cases.

\section{DISCUSSION}

In this study, we describe a new method to isolate DNA from stool, which has several advantages. It is unique to the method that crude stool is used and no specials pretreatment of patients or samples is necessary. Stool specimens can easily be collected by the patient because, other than dry storage, no specific conditions are required up to $48 \mathrm{~h}$ after samples are collected. Our method may be a further step in the development of a protocol to evaluate large numbers of samples. Furthermore, the amplification of single-copy human genes from isolated fecal DNA was possible in all cases, which indicates that the human genomic DNA was not 
degraded, at least in part. The amount of stool used for isolation was $2 \mathrm{~g}$. This factor is $2-10 \times$ greater than used in most other studies $(5,12,15)$, and so reduces the chance for a sampling error.

The fraction of human DNA in the samples isolated from stool is low. Human DNA could be detected with dot blotting in only $12 \%$ of the cases. A large variation in the amount of human DNA was observed and ranged from $0.06 \%-46 \%$.

With PCR, 40 cycles amplification of undiluted total fecal DNA did not lead to a visible product. When undiluted samples were spiked with a known amount of human genomic DNA, in only one case was a visible band demonstrated. This statistic is in agreement with other studies $(9,18)$. However, the human K-ras gene could be demonstrated in all diluted spiked samples, which emphasizes the presence of at least one inhibitor in fecal material that can be diluted from the samples. In general, the samples with high DNA yields needed higher dilutions in the PCR before a positive signal could be demonstrated. This may indicate that an excess of bacterial DNA inhibits PCR. The same theory may apply for dot blot hybridization. However, changing the DNA concentration with dot blotting did not improve the outcome. Remarkably, for samples with a similar fecal DNA concentration, a large variation was noticed in the dilution with the first positive signal in PCR. This result and the fact that three of nine cases positive for dot blotting did not show a visible PCR product after 40 rounds of PCR proves that another inhibitor may be present apart from bacterial DNA. Müller and Roth tried to separate the inhibitors by using an absorption matrix with carbohydrates and colestipolhydrochlorid, respectively $(3,16)$.

In our procedure, the effect of the inhibitors is diminished by dilution. A drawback of dilutions is that the initial concentration of human DNA in the PCR mixture may be low for the detection of single-copy genes after $40 \mathrm{cy}$ cles of amplification. This may explain the fact that only $41 \%$ of the cases were positive with a signal of variable intensity after the first round of PCR. The amount is similar to that described by Villa et al. (45\%) (19) for one round of
PCR. To increase the sensitivity for mutation detection in DNA extracted from stool, nested PCR has been performed before (2). Interestingly, in all stool samples irrespective of variation in consistency (1), human DNA could be demonstrated after a second round of amplification. Apparently, more cycles were necessary to clearly obtain visible bands after gel electrophoresis. Hybridization of the amplification products in the EXACCT procedure confirmed that the human K-ras gene was amplified in the consecutive amplification reactions. It is noteworthy that the EXACCT procedure has a higher specificity than in Southern blotting, for example, in which two probes with adequate hybridization are required before a signal is obtained.

The use of phenol in the first step of the isolation procedure has several advantages. The liquid phase at room temperature is used for mixing of the more compact stool. In addition, the polar nature will contribute further separation of lipophilic and hydrophilic components of the dissolved fractions. Moreover, the cooling in a dry ice-ethanol bath will result in freezing of the phenol with needle formation (4). This may have a local effect on membranes in the stool-buffer mixture. At this time, the mixture can be stored until further use. Freezing of the dry stool before using the isolation mixture leads to some degradation that is made visible with a more intense smear on agarose gels.

Before using stool for large-scale sceening of malignant diseases, several factors must still be studied and should focus mainly on selective isolation of human DNA. In a method described by Lapidus, cross sections from stool were taken with the intention of a representative sampling of tumor cells possibly attaching in a line on one side of the stool lump (10). Other factors are cooling the stool below its gel freezing point, with subsequent washing of the epithelial cells from the surface. (14) In methods described by Vogelstein and Kinzler, a stool lysis buffer is used to lyse eukaryotic cells for the subsequent separation of the bacteria by centrifugation $(17,23)$. In contrast, our method does not use a strategy of cell enrichment or separation of bacteria.

The limitations of our DNA isola- 
tion procedure from stool are a double phenol/chloroform extraction step and a dilution step that is frequently required for PCR, which leads to a decrease in the amount of tumor DNA that possibly drops under the detection limit. During our procedure, the heating step can possibly be avoided, while in stool with weak consistency, glass beads can be omitted. This step may lead to a relative increase of human DNA because the amount of lysed bacteria is likely to decrease. Up to now, patient compliance to our method was extremely high. Moreover, the DNA isolation method requires no specific sampling buffer. Both characteristics are suitable for large-scale screening.

\section{REFERENCES}

1.Degen, L.P. and S.F. Phillips. 1996. How well does stool form reflect colonic transit? Gut 39:109-113.

2.Deuter, R. and O. Muller. 1998. Detection of APC mutations in stool DNA of patients with colorectal cancer by HD-PCR. Hum. Mutat. 11:84-89.

3.Deuter, R., S. Pietsch, S. Hertel and O. Muller. 1995. A method for preparation of fecal DNA suitable for PCR. Nucleic Acids Res. 23:3800-3801.

4.Domdey, H., B. Apostol, R.-J. Lin, A. Newman, E. Brody and J. Abelson. 1984. Lariat structures are in vivo intermediates in yeast pre-mRNA splicing. Cell 39:611-621.

5.Eguchi, S., N. Kohara, K. Komuta and T. Kanematsu. 1996. Mutations of the $p 53$ gene in the stool of patients with resectable colorectal cancer. Cancer 77:1707-1710.

6.Harrison, T.R. 1998. Priniciples of Internal Medicine. 14th ed., p. 236. MacGraw-Hill, New York.

7.Hasegawa, Y., S. Takeda, S. Ichii, K. Koizumi, M. Maruyama et al. 1995. Detection of $\mathrm{K}$-ras mutations in DNAs isolated from feces of patients with colorectal tumors by mutantallele-specific amplification (MASA). Oncogene 10:1441-1445.

8.Holloway, B., D.D. Erdman, E.L. Durigon and J.J. Murtagh. 1993. An exonucleaseamplification coupled capture technique improves detection of PCR product. Nucleic Acids Res. 21:3905-3906.

9.Hopwood, A.J., A. Mannucci and K.M. Sullivan. 1996. DNA typing from human faeces. Int. J. Legal Med. 108:237-243.

10.Lapidus, S.N., A.P. Shuber and K.M. Sullivan, inventors. Methods for detecting colon cancer from stool samples, US patent 5741650. 1998, 21 April.

11.Loktionov, A., I.K. O'Neill, K.R. Silvester, J.H. Cummings, S.J. Middleton and R. Miller. 1998. Quantitation of DNA from exfoliated colonocytes isolated from human stool surface as a novel noninvasive screening test for colorectal cancer. Clin. Cancer Res. 4:337342 .

12.Maniatis, T. 1997. Current protocols in molecular biology. John Wiley and sons, Inc. USA. Dot blotting of DNA onto a positively charged nylon membrane using a manifold. Vol 3 S21; 2.9 .18

13.Nollau, P., C. Moser, G. Weinland and C. Wagener. 1996. Detection of K-ras mutations in stools of patients with colorectal cancer by mutant-enriched PCR. Int. J. Cancer 66:332336.

14.O'Neill, I.K. inventor. Method of isolating cells, US patent 97/09600, GB. 1997, 13 March

15.Ratto, C., G. Flamini, L. Sofo, P. Nucera, M. Ippoliti, G. Curigliano, G. Ferretti, A. Sgambato et al. 1996. Detection of oncogene mutation from neoplastic colonic cells exfoliated in feces. Dis. Colon Rectum 39:12381244.

16.Roth, W.K. inventor. Verfahren zur Reinigung von Nukleinsauren oder zur Isolierung von Nukleinsauren aus korperzellenhaltigen Proben unter gleichzeitiger Abreinigung von PCR-Inhibitoren, US Patent 19638362 C1, DE. 1998, 12 February.

17.Sidransky, D., T. Tokino, S.R. Hamilton, K.W. Kinzler, B. Levin, P. Frost and B. Vogelstein. 1992. Identification of ras oncogene mutations in the stool of patients with curable colorectal tumors. Science 256:102-105.
18.Smith-Ravin, J., J. England, I.C. Talbot and W. Bodmer. 1995. Detection of c-Ki-ras mutations in faecal samples from sporadic colorectal cancer patients. Gut 36:81-86.

19.Somers, V.A.M.C., A.M. Pietersen, P.H.M.H. Theunissen and F.B.J.M.Thunnissen. 1998. Detection of K-ras point mutations in sputum from patients with adenocarcinoma of the lung by Point-EXACCT. J. Clin. Oncol. 16:3061-3068.

20.Tobi, M., F.C. Luo and Z. Ronai. 1994. Detection of K-ras mutation in colonic effluent samples from patients without evidence of colorectal carcinoma [see comments]. J. Natl. Cancer Inst. 86:1007-1010.

21.Thunnissen, personal observation, picture available.

22.Villa, E., A. Dugani, A.M. Rebecchi, A. Vignoli, A. Grottola, P. Buttafoco, L. Losi, M. Perini, P. Trande, A. Merighi, R. Lerose and F. Manenti. 1996. Identification of subjects at risk for colorectal carcinoma through a test based on K-ras determination in the stool. Gastroenterology 110:1346-1353.

23.Vogelstein, B. and K.W. Kinzler, inventors. Methods of detecting mammalian nucleic acids isolated from stool specimen and reagents therefor, US Patent: 93/20235. 1993, 14 October.

24.Yoshida, K., T. Sugino, J. Bolodeoku, B.F. Warren, S. Goodison, A. Woodman, T. Toge, E. Tahara and D. Tarin. 1996. Detection of exfoliated carcinoma cells in colonic luminal washings by identification of deranged patterns of expression of the CD44 gene. J. Clinical Patholog. 49:300-305.

This study was funded by ZON (Zorg Onderzoek Nederland) project no. 28-2716. Address correspondence to Dr. F.B.J.M. Thunnissen, Department of Pathology, Canisius Wilhelmina Hospital, Molecular Division C66, PO Box 9015, 6500 GS Nijmegen, The Netherlands. Internet: e.thunnissen@ cwz.nl

Received 22 June 1999; accepted 14 October 1999.

B.M. Machiels, T. Ruers ${ }^{1}$, M.

Lindhout, K. Hardy, T. Hlavaty, D.D. Bang, V.A.M.C. Somers, C. Baeten, $M$. von Meyenfeldt and F.B.J.M. Thunnissen Maastricht University Maastricht

${ }^{1}$ Nijmegen University

Nijmegen

The Netherlands 